\title{
Comparative assessment of livelihood vulnerability of climate induced migrants: a micro level study on Sagar Island, India.
}

\section{Evaluación comparativa de la vulnerabilidad de los medios de vida de los migrantes inducidos por el clima: un estudio a nivel micro en la isla Sagar, India.}

Aparna Bera ${ }^{1}$, Dr Suraj Kumar Singh ${ }^{2}$

1- Research Scholar, Suresh Gyan Vihar University, Jaipur; email: aparna.62232@mygyanvihar.com

2- Corresponding Author, Associate Professor\& HOD of Centre for Sustainable Development, Suresh Gyan Vihar University, Jaipur; email: suraj.kumar@mygyanvihar.com

\section{ABSTRACT}

The effects of climate change are causing large scale human displacements over past few decades. Climate refugees are putting biggest challenges to the geophysical biological and social system all over the world. This paper attempts to assess and compare the vulnerability of the climate induced migrants and regular settlers of selected mouzas of Sagar Island, south 24parganas, India. People are witnessing their lands vanishing under their feet in these constantly sinking and shrinking deltaic estuaries of Sundarban. Findings of LVI and LVI-IPCC analysis indicate that the climate induced migrant communities are more exposed to climatic variability due to the poor adaptive capacity. Moreover poor access to food, water, health facilities are making them extremely vulnerable with lower resilience as these mouzas are facing frequent flooding, severe coastal erosion, embankment breaching and higher storm surges on annual basis. The outcomes of this study could be beneficial in effective on site risk management and planning propositions.

Keywords: Climate Induced Migrants, Sagar Island, Livelihood Vulnerability Index (LVI), Resilience, Adaptation Strategies. 
Sustainability, Agri, Food and Environmental Research, (ISSN: 0719-3726), 9(2), 2021: 216-230 http://dx.doi.org/10.7770/safer-V0NO-art2324

\section{RESUMEN}

Los efectos del cambio climático están provocando desplazamientos humanos a gran escala en las últimas décadas. Los refugiados climáticos están planteando los mayores desafíos al sistema geofísico, biológico y social en todo el mundo. Este artículo intenta evaluar y comparar la vulnerabilidad de los inmigrantes inducidos por el clima y los colonos habituales de determinadas mouzas de la isla Sagar, al sur de 24parganas, India. La gente está presenciando cómo sus tierras se desvanecen bajo sus pies en estos estuarios deltaicos de Sundarban que se hunden y encogen constantemente. Los resultados del análisis de LVI y LVIIPCC indican que las comunidades de migrantes inducidas por el clima están más expuestas a la variabilidad climática debido a la escasa capacidad de adaptación. Además, el acceso deficiente a los alimentos, el agua y las instalaciones sanitarias los hace extremadamente vulnerables con menor capacidad de recuperación, ya que estas mozas se enfrentan a inundaciones frecuentes, erosión costera severa, rupturas de terraplenes y marejadas ciclónicas más altas anualmente. Los resultados de este estudio podrían ser beneficiosos en propuestas efectivas de planificación y gestión de riesgos en el sitio.

Palabras clave: Migrantes inducidos por el clima, Isla Sagar, Índice de vulnerabilidad de los medios de vida (LVI), Resiliencia, Estrategias de adaptación.

\section{Introduction}

The effects of climate change are causing large scale human displacements all over the World for past few decades. With a rise in both rapid-onset extreme events and slow onset climate phenomena, people have been more and more forced to leave their habitat and migrate elsewhere. Zhang et al, (2008) mentioned these climate induced migrants; climate refugees are putting biggest challenge to the humanity as climate change can jeopardize many geophysical, biological and social system (Zhang et al, 2008).

Over 19.3 million people were displaced worldwide in 2014, which could be one billion by 2050 (Internal Displacement Monitoring Centre, Geneva). The most vulnerable groups are poor in the coastal areas and small islands of developing countries. Their poor adaptive capacity and lack of sustainable livelihoods demand broader aspects of effective governance and management policies. The $16^{\text {th }}$ session UNFCC 2011 has called for a better understanding of this looming crisis from the angle of human rights of these socially marginalized and displaced people (Zhang et al 2008).

Cutter et al, (2000) mentioned livelihood vulnerability to climate change is a product of both bio-physical and social factors (Cutter et al, 2000). Shah et al, (2013) mentioned biophysical vulnerability emerges from the exposure of communities to climate changes, while 
Sustainability, Agri, Food and Environmental Research, (ISSN: 0719-3726), 9(2), 2021: 216-230 http://dx.doi.org/10.7770/safer-VONO-art2324

social vulnerability is the product of those factors that make communities more susceptible to such phenomena (Shah et al, 2013). Dankelman, (2010) mentioned landmark research on climate change has correlated such phenomena with a greater disruption of food, water, health and livelihood security (FAO, 2007) of the individuals, households and community concerned (Dankelman, 2010). IPCC warned in 2014, that the low-lying coastal areas will continue to experience sea level rise, increasing winter temperature, intensification of cyclones, coastal flooding, salt water intrusion and loss of land and mangroves.

Ghosh (2012) mentioned this imprints of despair are evident in the Sundarban where the fragility of the ecosystem, underdevelopment and an over dependence of the people on climate sensitive substance have made the population more vulnerable (Ghosh, 2012). World's largest contiguous mangrove forest, a UNESCO World Heritage site and one of the mostly modified and highly vulnerable deltaic estuaries are already reeling under the impacts of climate change in the form of more turbulent seas, increasing salinity and frequent storm surges. WWF India, (2009) stated Indian Sundarban originally consisted of 102 islands but now 98 islands are in existence as 4 I islands have been submerged and nearly 6000 families turned into environmental migrants (WWF India, 2009). Due to accelerating rate of sea level rise, embankment breaching and coastal erosion nearly 1.4 million people in 53 Islands are facing serious threats of becoming homeless. Mitra et al. mentioned some islands are fast vanishing from the map causing thousands of people displaced from their original habitat (Mitra et al.) The level of sea around the island is rising at an alarming rate of $2.36 \mathrm{~mm}$ per year, higher than Global overage of $2.0 \mathrm{~mm}$ year (S.Hazra,2002). Based on the current habitation and density by 2020 more than 30,000 people residing in Sagar Island will be displaced from their habitat (S. Hazra,2002). People of these constantly sinking and shrinking landmasses are also threatened by unmanageable demographics, large scale poverty, marginalized livelihoods and limited economic development.

Eriksen et al, (2007) mentioned globally research concerning the human dimensions of environmental change and policy formation applies vulnerability assessment methods to identify vulnerable areas and population to frame and implement policies for possible mitigation and disaster risk reduction (Eriksen et al, 2007, Abson et al, 2012, Mondal et al, 2018). Flagship studies have already been assigned vulnerability in the context of climate change and outlined its main components as Exposure, Sensitivity and adaptive capacity. Ebi $k$, (2006) stated exposure is the extent to which a system is in contact with a change in climate; sensitivity is the degree to which the community is affected by the exposure and adaptive capacity is the system's ability to withstand or recover from the change in climate (Ebi k, 2006). Livelihood vulnerability Index (LVI) developed by Hahn et al, (2009) following the IPCC livelihood vulnerability framework is one of the most effective methods used by researchers worldwide. Though the complex phenomena of climate change have been generalized by the vulnerability indices, the advantage of such assessment is its 
Sustainability, Agri, Food and Environmental Research, (ISSN: 0719-3726), 9(2), 2021: 216-230 http://dx.doi.org/10.7770/safer-VONO-art2324

instrumentation as this can be used to determine and evaluate policy requirements, adaptation strategies and mitigation of climate risks.

The main objective of this study is to investigate the impact of climate variability on migration; assess their socio-economic vulnerability, associated problems, and evaluate rehabilitation strategy, policy response and suggest effective adaptation measures.

Recent research works on Sagar Island have explored aspects like environmental hazards, shoreline change, coastal erosion, degradation of ecosystem, depletion of mangroves. Realizing the need of better understanding of the impact of climate variability on livelihood vulnerability, the present study is an attempt to compare the cumulative effects of natural hazards, storm surges, coastal erosion, embankment breaching on the livelihood vulnerability of local and refugee population of the Gangasagar Gram Panchayat of Sagar Island under the Indian Sundarban.

The LVI carries multiple indicators to assess the exposure of the community to climate variation and natural disasters through the perception survey in selected mouzas. Current health and food status, water resource characteristics are calculated to determine the adaptive capacity. This evaluative study on the degree of vulnerability of two distinctive communities to climate change can be used to formulate appropriate adaptation strategies for the government and non-government organization to address area and community specific intervention and policy development.

\section{MATERIAL AND METHODS}

Study Area: The study area (Fig.-1) \& (Table-1) is the GangaSagar Gram Panchayat in the Sagar block of Kakdwip sub-division of South 24-Parganas district of India. Sagar Island, the largest island in the Sundarban is part of a tidally active delta formed by alluvium of Ganga and Brahmaputra and their tributaries.

These low lying marshy alluvial plains are still in the process of being formed and reformed by continuous siltation and tidal erosion. Land reclamation started in 1811, under the British rulers. The total geographical area of the Pahchayat consisting of 8 mouzas namely Sagar (dialuvated), Beguyakhali, GangaSagar, Mahismari, Chandipur, Bishnupur, Natendrapur, and Narayani Abad is $41.27 \mathrm{sq} \mathrm{km}$. There are 2030 houses consisting total population of 10,340 in Gangasagar mouza. Sex ratio is 978 , literacy rate is $83.56 \%$ and poverty ratio is $44.46 \%$ ( 2011 Census). Out of 3755 total workers, 1498 people are marginal workers. Majority of population make out a precarious living on this flood and cyclone prone land by farming, fishing, collecting prawn seeds. Marginal workers depend on seasonal tourism during the annual fair at Gangasagar and for the rest of the year they become daily laborers. 
After 2009 cyclone Aila, most of the agricultural lands became barren and converted into aquaculture ponds due to saline water intrusion.

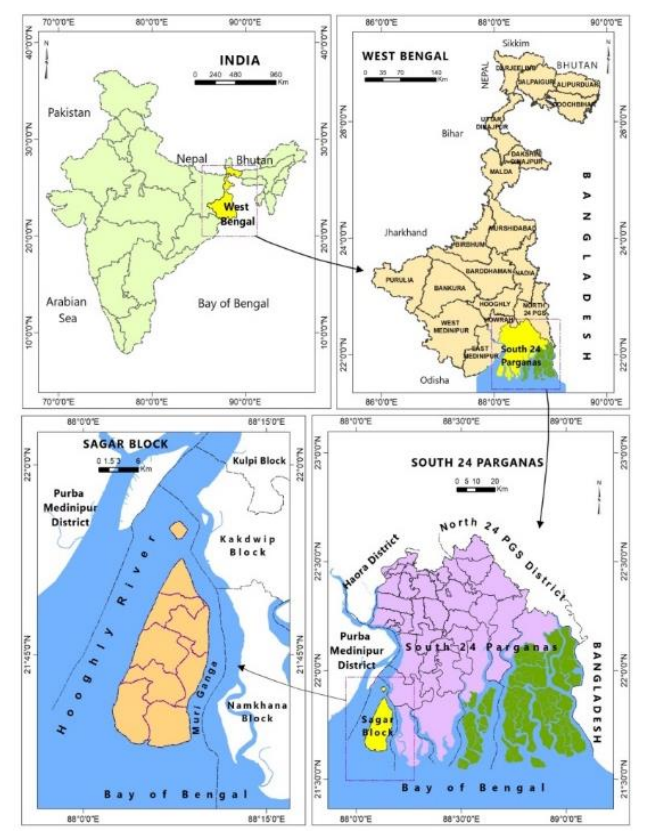

Fig-1: Study area

Table 1: Study area at a glance

\begin{tabular}{cccccc}
\hline Mouza & Gram Panchayat & Block & Area (sq.km) & Population & Population density \\
\hline Gangasagar & GangaSagar & Sagar & 12.25 & 10340 & 844 \\
Beguyakhali & GangaSagar & Sagar & 6.49 & 5683 & 876 \\
\hline
\end{tabular}

Source: Gangasagar Bakhali Development Authority \& Census 2011

Mondal et al. (2017) mentioned greater exposure to climate-driven hazards and a high dependency of rural people on a rain feed agrarian economy made the island for a significant part of the global climate change debate and discussions.

On the basis of District Disaster report, World Bank report, Newspaper reporting; consultation with expert officials of Directorate of Land Record and Survey, Sundarban Development Authority, Irrigation Department and local indigenous people; two mouzas of Gangasagar Gram Panchayat were selected to comprise the reviewed area based on the severity of erosion. Extensive primary field surveys with secondary official data were collected to identify the immigrated areas, where they were resettled on rayati lands from $1980 \mathrm{~s}$.

The mouzas located in the south-eastern part of the Gangasagar Gram Panchayat, i.e. Beguyakhali and part of Mahismari has experienced greater erosion compared to the rest of the mouzas (S. Hazra,2002). Both the random and purposive sampling techniques were applied to collect household data of regular and refugee settlers of Gangasagar and 
Beguyakhali mouza as rest of the mouzas is not affected by climate induced migrant population. Structured questionnaires were prepared to survey 15 percent of the households with no bias correction because of the homogenity of the population. Bartlett et al. (2001) stated It has been argued that $5 \%$ of the population is adequate for a cross sectional household survey (Bartlett et al. 2001). This comparative livelihood analysis survey was conducted from May-July 2019 on socio-demographic profile and climatic variability of the sample population.

The Landsat2(MSS)1977, Landsat5(TM)1989, Landsat8(OLI)2017 were used to identify changes in shoreline and current land use pattern in the study area and maps were prepared using Arc GIS 10.2.1.

The livelihood vulnerability Index (LVI) proposed by Hahn et al. (2009) following IPCC vulnerability framework was adopted in this study. Each major component has various sub components and each sub component contributes equally to the overall index (Table-4). The results are evaluated on a scale of 0 (least vulnerable) to 1 (most vulnerable). A balanced weighted approach was followed for the LVI calculation (Hahn et al., 2009; Pandey and Jha, 2012). The values were standardized as:

$$
S d=(S d-S \min ) /(S \max -S \min )
$$

Where Sd is the sub-component for an area ' $d$ ' and the minimum ( $\mathrm{S} \mathrm{min)}$ and maximum (S max) values for each sub-component. After being standardized, the sub-components are averaged by following:

$$
\mathrm{Md}=\sum_{i=1}^{n} \mathrm{Sdi} / n
$$

Where Md is one of the eight major components for an area ' $d$ ', Sdi denotes the sub component, indexed by $\mathrm{i}$ and $\mathrm{n}$ indicates number of sub component for the major components. Once the values of each of the eight major components are calculated, they are averaged to obtain the LVI using:

$$
\text { LVI d }=\sum_{i=l}^{n} \text { Wmi x Mdi } / \sum_{i=l}^{n} \text { Wmi }
$$

Where LVI $d$ is the LVI score of the area ' $d$ ' and Wmi is the weight by the subcomponents that form major component $\mathrm{i}$.

The LVI-IPCC differentiates from the LVI by IPCC vulnerability definition. As the major components are combined; (1) Exposure of the community is measured by their perception of natural disasters and climatic variation, (2) Sensitivity is assessed health, food, water and social safety and (3) Adaptive capacity is quantified by socio demographic profile, livelihood 
strategies and social safety. This score varies from - 1 (least vulnerable) to 1 (most vulnerable) and is calculated as:

$$
\mathrm{CFd}=\sum_{i=l}^{n} \mathrm{Wmix} \mathrm{Mdi} /=\sum_{i=l}^{n} \mathrm{Wmi}
$$

CFd is a contributing factor for mouza ' $d$ ', Mdi are major components for area ' $d$ ' indexed by $\mathrm{i}, \mathrm{Wmi}$ is the weight of each major component. Once the exposure, sensitivity and adaptive capacity were calculated, these three are combined using:

$$
\text { LVI }- \text { IPCC } d=(e d-a d) x \text { sd }
$$

In LVI-IPCC is the LVI for mouza'd', ed is the score of exposer, ad is the score of adaptive capacity and sd is the score of sensitivity.

\section{RESULT AND DISCUSSIONS}

Impact on Migration: Hazra et al, (2017) mentioned the impact of continuous erosion and accretion process on human activity is mostly felt along the coastal zones of island systems. The study area faced considerable changes in shoreline from 1978 (Figure-2). Heavily eroded vulnerable embankments of Beguyakhali are causing people to move towards interior. There has been a change in land use pattern due to land loss in the coastal areas. Overall decrease in agricultural land, vegetation and increase in settlement, inundated land is evident.

Fig: 2-

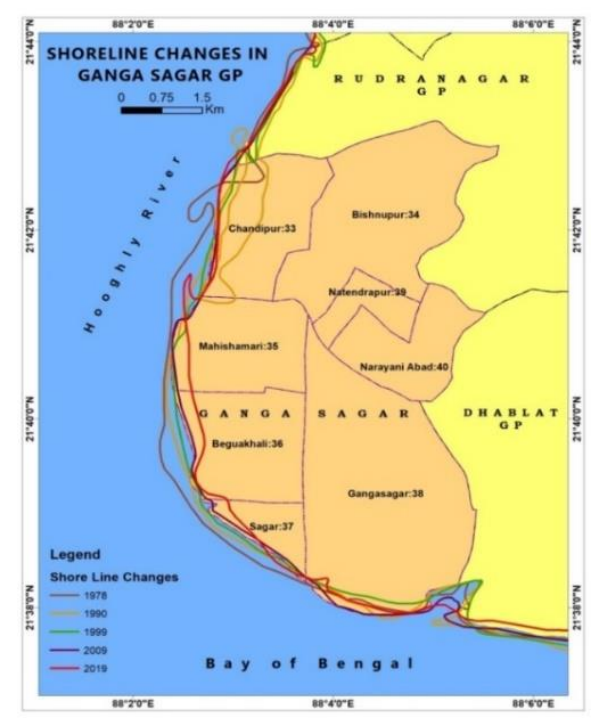

Change (1978-2019) and LULC map of Ganga Sagar GP (Source: Computed by author)

Vanishing lands mean displacements and loss of livelihoods. But the state government is yet to come up with a sustainable and coherent resettlement policy. Refugees from Lohachara and 
Sustainability, Agri, Food and Environmental Research, (ISSN: 0719-3726), 9(2), 2021: 216-230 http://dx.doi.org/10.7770/safer-V0N0-art2324

lost bits of Ghoramara and some other mouzas currently add up to almost 6,000 in no. The local block administration used to resettle them on rayati land allotting two to one-sixth acres per family (Fig-3) \& (Table-2).

The paddy grown on these tiny plots fails to feed them for more than a few months. Due to lack of industries or other organized employment options, even regular settlers have to rely on daily wage labor or take up manual jobs in big cities. Around $40 \%$ of the population has at least one male member working outside. Household survey revealed that almost $70 \%$ of the migrants have lost their original livelihoods for coastal flooding and inundation. Before migration they had 4-5 acres of agricultural lands on an average but now most of them have been turned into seasonal opportunistic laborers.

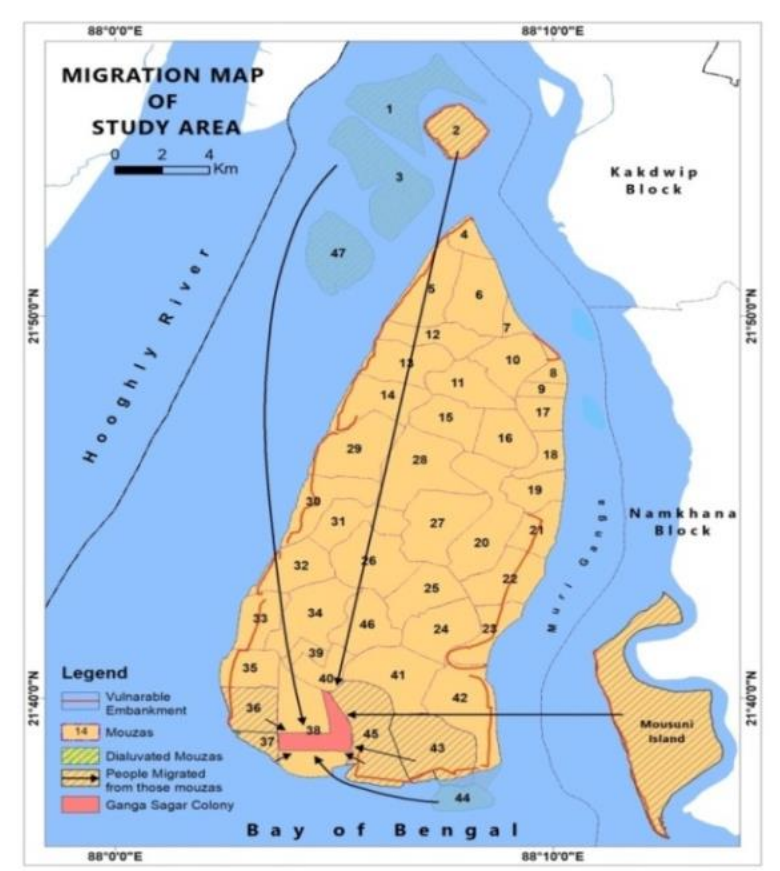

Fig-3: Migration map of Study area (Source: Computed by author)

Table-2: Resettlements of climate migrants

\begin{tabular}{cccc}
\hline $\begin{array}{c}\text { Resettled in } \\
\text { Rayati Settlements of }\end{array}$ & Emigrated from & $\begin{array}{c}\text { Alotte } \\
\text { (no. of families) }\end{array}$ & $\begin{array}{c}\text { Area allotted } \\
\text { per family in Acres }\end{array}$ \\
\hline Gangasagar & Lohachara & 154 & 1.30 \\
(Gangasagar Colony) & Ghoramara & 142 & .05 \\
& Boatkhali & 78 & .05 \\
& Mousuni Island & 20 & .05 \\
Beguyakhali & Mahismari & 80 & .05 \\
& Beguyakhali & 35 & .05 \\
& Embankment side & & \\
\hline
\end{tabular}

Source: Primary Survey and BLRO, Sagar 
Sustainability, Agri, Food and Environmental Research, (ISSN: 0719-3726), 9(2), 2021: 216-230 http://dx.doi.org/10.7770/safer-V0N0-art2324

Researchers ascertain that Sagar Island is likely to lose more lands in coming years. With increasing pressure of refugees there has been increasing grievance about reduced farm lands, depleted vegetation cover and deteriorated ecological balance. Moreover, in coming 1015 years, remaining 5,400 residents of Ghoramara and some more from surrounding will come for rehabilitation putting significant threat to the existing settlers. Though all measures of rehabilitations so far have been on ad-hoc basic without any inclusive management plan. Climate induced hazards have been effecting the basic facilities of food, shelter, health, education, drinking water and minimum infrastructural support here.

LVI Analysis: Table: 3 displays the values of the main components and standardized sub-components for the comparative LVI analysis of refugees (resettled) and regular settlers of Beguyakhali and Gangasagar mouzas of Ganga Sagar G.P. Higher the index value, higher is the vulnerability and vice versa. Higher vulnerability are observed in refugee settlers of Gangasagar (0.078) and Beguyakhali (0.620), while the regular settlers project lower vulnerability in overall LVI score.

Table 3: Indexed values of Livelihood Vulnerability Index (LVI) of the two mouzas of Sagar Island

\begin{tabular}{|c|c|c|c|c|}
\hline \multirow[t]{2}{*}{ Components } & \multicolumn{2}{|c|}{ Beguakhali } & \multicolumn{2}{|c|}{ GangaSagar } \\
\hline & Regular & Migrant & Regular & Migrant \\
\hline 1. Socio-Demographic Profile & 0.47 & 0.434 & 0.461 & 0.483 \\
\hline Dependency ratio & 0.395 & 0.385 & 0.308 & 0.37 \\
\hline$\%$ of female-headed $\mathrm{HHs}$ & 0.025 & 0.079 & 0.17 & 0.161 \\
\hline$\%$ of $\mathrm{HH}$ where head of family did not attend school & 0.321 & 0.195 & 0.45 & 0.192 \\
\hline$\%$ of $\mathrm{HHs}$ where head is the only earning member & 0.632 & 0.628 & 0.657 & 0.765 \\
\hline Average number of family members in a $\mathrm{HH}$ & 0.498 & 0.49 & 0.39 & 0.45 \\
\hline$\%$ of HHs with a non-climate-resilient home & 0.95 & 0.83 & 0.795 & 0.961 \\
\hline 2. Livelihood Strategy & 0.56 & 0.697 & 0.409 & 0.562 \\
\hline$\%$ of HHs where family members migrate for work & 0.618 & 0.723 & 0.585 & 0.57 \\
\hline$\%$ of $\mathrm{HHs}$ dependent on natural resources & 0.918 & 0.998 & 0.449 & 0.984 \\
\hline $\begin{array}{l}\% \text { of } \mathrm{HHs} \text { where agriculture is the main source of } \\
\text { income }\end{array}$ & 0.402 & 0.632 & 0.272 & 0.42 \\
\hline$\%$ of earning members in a family & 0.302 & 0.435 & 0.333 & 0.277 \\
\hline 3. Health & 0.547 & 0.501 & 0.165 & 0.515 \\
\hline $\begin{array}{l}\% \text { of } \mathrm{HHs} \text { who find it difficult to reach health } \\
\text { facilities }\end{array}$ & 0.825 & 0.95 & 0.79 & 0.96 \\
\hline $\begin{array}{l}\% \text { of } \mathrm{HHs} \text { whose family members died without } \\
\text { treatment during natural hazards }\end{array}$ & 0.22 & 0.205 & 0.313 & 0.232 \\
\hline
\end{tabular}


Sustainability, Agri, Food and Environmental Research, (ISSN: 0719-3726), 9(2), 2021: 216-230 http://dx.doi.org/10.7770/safer-V0N0-art2324

\begin{tabular}{|c|c|c|c|c|}
\hline$\%$ of HHs without a sanitary latrine & 0.452 & 0.692 & 0.192 & 0.802 \\
\hline$\%$ of $\mathrm{HHs}$ where members suffer from illness & 0.48 & 0.578 & 0.728 & 0.505 \\
\hline$\%$ of HHs not visiting doctors during illness & 0.76 & 0.081 & 0.482 & 0.076 \\
\hline 4. Food & 0.804 & 0.78 & 0.086 & 0.785 \\
\hline$\%$ of $\mathrm{HHs}$ that do not get food from the family farm & 0.498 & 0.479 & 0.79 & 0.572 \\
\hline $\begin{array}{l}\% \text { of } \mathrm{HHs} \text { reporting decreasing regeneration of } \\
\text { green leafy vegetables }\end{array}$ & 0.575 & 0.798 & 0.743 & 0.695 \\
\hline$\%$ of $\mathrm{HHs}$ losing agricultural land & 0.65 & 0.852 & 0.79 & 0.967 \\
\hline $\begin{array}{l}\% \text { of } \mathrm{HHs} \text { reporting decreasing agricultural } \\
\text { production }\end{array}$ & 0.794 & 0.639 & 0.623 & 0.615 \\
\hline $\begin{array}{l}\% \text { of } \mathrm{HH} \text { reporting increasing food insecurity during } \\
\text { natural disasters or other climatic events }\end{array}$ & 0.805 & 0.98 & 0.586 & 0.921 \\
\hline$\%$ of $\mathrm{HHs}$ reporting decreasing fish production & 1.503 & 0.933 & 0.827 & 0.944 \\
\hline 5. Water & 0.515 & 0.706 & 0.538 & 0.666 \\
\hline $\begin{array}{l}\% \text { of HHs who walk more than } 2 \mathrm{~km} \text { to reach a water } \\
\text { source }\end{array}$ & 0.372 & 0.732 & 0.515 & 0.691 \\
\hline $\begin{array}{l}\% \text { of HHs using unsafe water for drinking, cooking, } \\
\text { bathing and washing }\end{array}$ & 0.542 & 0.768 & 0.652 & 0.886 \\
\hline$\%$ of $\mathrm{HHs}$ reporting water conflict & 0.632 & 0.62 & 0.448 & 0.423 \\
\hline 6. Social Safety & 0.397 & 0.542 & 0.578 & 0.523 \\
\hline $\begin{array}{l}\% \text { of HHs who do not receive assistance from a } \\
\text { social network }\end{array}$ & 0.015 & 0.185 & 0.413 & 0.035 \\
\hline $\begin{array}{l}\% \text { of HHs who do not receive assistance from the } \\
\text { Government }\end{array}$ & 0.948 & 0.825 & 0.93 & 0.926 \\
\hline$\%$ of $\mathrm{HHs}$ who do not receive assistance from NGOs & 0.91 & 0.95 & 0.966 & 0.963 \\
\hline $\begin{array}{l}\% \text { of HHs who do not use mobile phones for } \\
\text { communication }\end{array}$ & 0.002 & 0.032 & 0.201 & 0.002 \\
\hline$\%$ of unaware $\mathrm{HHs}$ & 0.112 & 0.43 & 0.384 & 0.69 \\
\hline 7. Natural disasters & 0.45 & 0.463 & 0.723 & 0.596 \\
\hline $\begin{array}{l}\% \text { of } \mathrm{HHs} \text { reporting increased frequency and } \\
\text { intensity of storm surges and tidal surges }\end{array}$ & 0.941 & 0.662 & 0.791 & 0.895 \\
\hline $\begin{array}{l}\% \text { of } \mathrm{HHs} \text { with an injury or death as a result of } \\
\text { natural disasters }\end{array}$ & 0.153 & 0.178 & 0.588 & 0.232 \\
\hline $\begin{array}{l}\% \text { of HHs with an injury or death to their livestock } \\
\text { as a result of natural disasters }\end{array}$ & 0.123 & 0.479 & 0.481 & 0.46 \\
\hline$\%$ of $\mathrm{HHs}$ with losses of physical assets & 0.952 & 0.928 & 0.966 & 0.914 \\
\hline $\begin{array}{l}\% \text { of } \mathrm{HHs} \text { that do not receive warning before a } \\
\text { natural disaster }\end{array}$ & 0.082 & 0.072 & 0.793 & 0.482 \\
\hline
\end{tabular}


Sustainability, Agri, Food and Environmental Research, (ISSN: 0719-3726), 9(2), 2021: 216-230 http://dx.doi.org/10.7770/safer-VONO-art2324

\begin{tabular}{|c|c|c|c|c|}
\hline 8. Climatic Variation & 0.706 & 0.898 & 0.641 & 0.877 \\
\hline $\begin{array}{l}\% \text { of } \mathrm{HHs} \text { reporting a change in summer } \\
\text { temperature }\end{array}$ & 0.842 & 0.972 & 0.802 & 0.96 \\
\hline$\%$ of $\mathrm{HHs}$ reporting a change in winter temperature & 0.631 & 0.612 & 0.648 & 0.655 \\
\hline $\begin{array}{l}\% \text { of } \mathrm{HHs} \text { reporting variation in monsoon } \\
\text { precipitation }\end{array}$ & 0.895 & 0.972 & 0.66 & 0.806 \\
\hline$\%$ of $\mathrm{HHs}$ reporting a change in winter precipitation & 0.842 & 0.997 & 0.712 & 0.983 \\
\hline $\begin{array}{l}\% \text { of HHs reporting a change in the frequency of } \\
\text { floods }\end{array}$ & 0.323 & 0.939 & 0.383 & 0.981 \\
\hline Score & 0.562 & 0.62 & 0.475 & 0.678 \\
\hline
\end{tabular}

$\mathrm{HH}$; Household NGO; Non-Governmental Organization (Source : Computed by author)

In the index of socio-demographic profile refugee settlers of Gangasagar are more vulnerable (0.483) while in livelihood strategy, refugee settlers of Beguyakhali show more vulnerability (0.697). Inadequate access to health services tends to increase the health index and increase the vulnerability among the refugee settlements. Food security builds resilience to external stressors like extreme climate events. Regular settlers of Beguyakhali have the higher vulnerability (0.804) followed by refugees of Gangasagar (0.785) as the southern parts of Sagar and Beguyakhali have been heavily eroded. The vulnerability index of the water component of LVI shows that refugee settlers are more vulnerable than the regulars due to scarcity of consistent supply and raised water conflict. In terms of social network refugee community reflects more vulnerability in seeking assistance from local Govt. authorities.
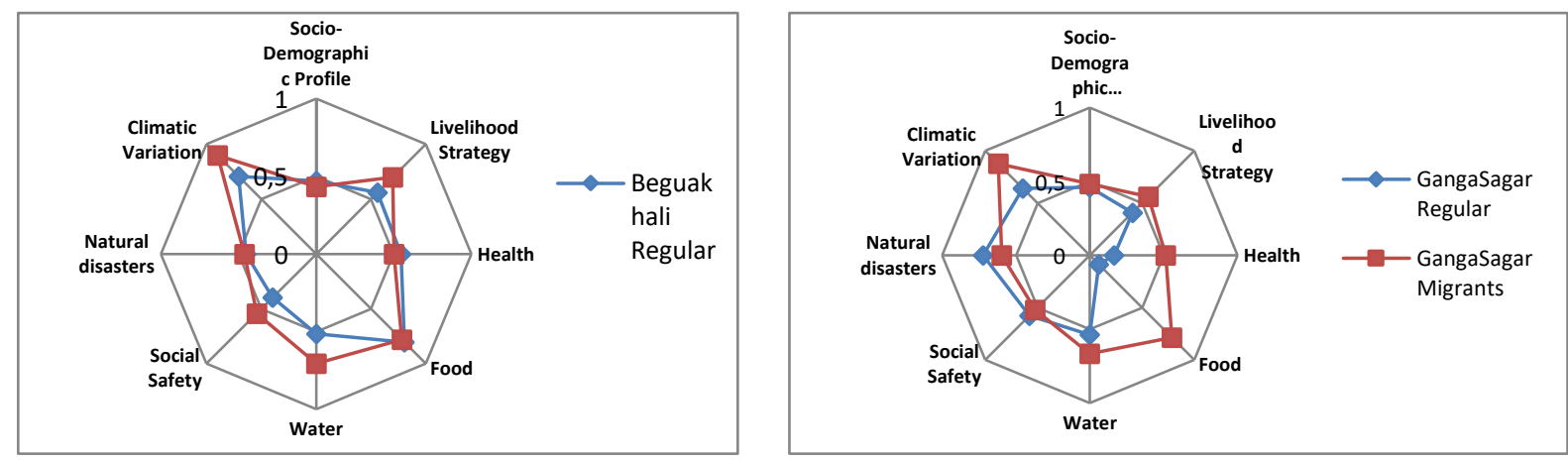
Fig-4: the vulnerability spider diagram ranges between 0 vulnerable) to 1 (extremely vulnerable) of the major components of the LVI for Beguyakhali and Gangasagar mouza. (Source: Computed by author)

Index of natural disaster shows almost same higher vulnerability in both the refugee and regular settlers, while Gangasagar mouza recorded greater vulnerability to the average number of natural hazard events. The results revealed that both the mouzas are vulnerable to the effects of climatic variability and variability but refugee settlers of both the mouzas are more vulnerable. (Fig: 4). The LVI-IPCC estimates of vulnerability which combines the degree of exposure sensitivity and adaptive capacity of a community reflects that the refugee population in both the mouzas is not resilient to the climatic variability.

Table: 4 Livelihood Vulnerability Index LVI-IPCC

\begin{tabular}{ccccc}
\hline & \multicolumn{2}{c}{ Beguyakhali } & \multicolumn{2}{c}{ GangaSagar } \\
\hline & Regular & Migrants & Regular & Migrants \\
Exposure & 0.578 & 0.68 & 0.682 & 0.736 \\
Sensitivity & 0.65 & 0.7 & 0.211 & 0.663 \\
Adaptive Capacity & 0.409 & 0.54 & 0.486 & 0.517 \\
LVI-IPCC Score & 0.07 & 0.098 & 0.041 & 0.145 \\
\hline
\end{tabular}

(Source : Computed by author)

Table: 4 Shows that the adaptive capacity of both the population varies from 0.409 to 0.540 , the degree of exposure and sensitivity is making the refugee population of both the mouzas are more vulnerable. This LVI-IPCC analysis shows that the resettled refugee population of Gangasagar are highly vulnerable (0.145), followed by the same of Beguyakhali (0.098), whereas the regular population of those mouzas reflect moderate vulnerability with 0.041 and 0.070 score respectively. (fig:5). If both the LVI \& LVI IPCC indices are compared, resettlers of both mouzas score maximum as they have experienced severe embankment breaching flooding and coastal erosion.(fig:6)

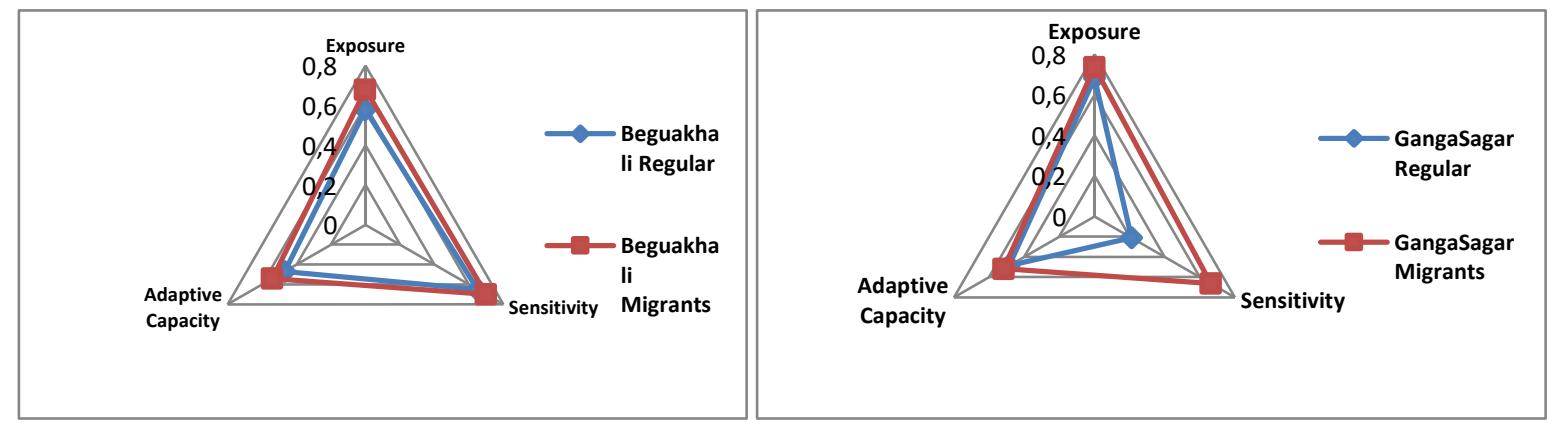


Fig-5: Vulnerability Triangle Diagram of LVI-IPCC for Beguyakhali an Gangasagar mouza (Source: Computed by author)

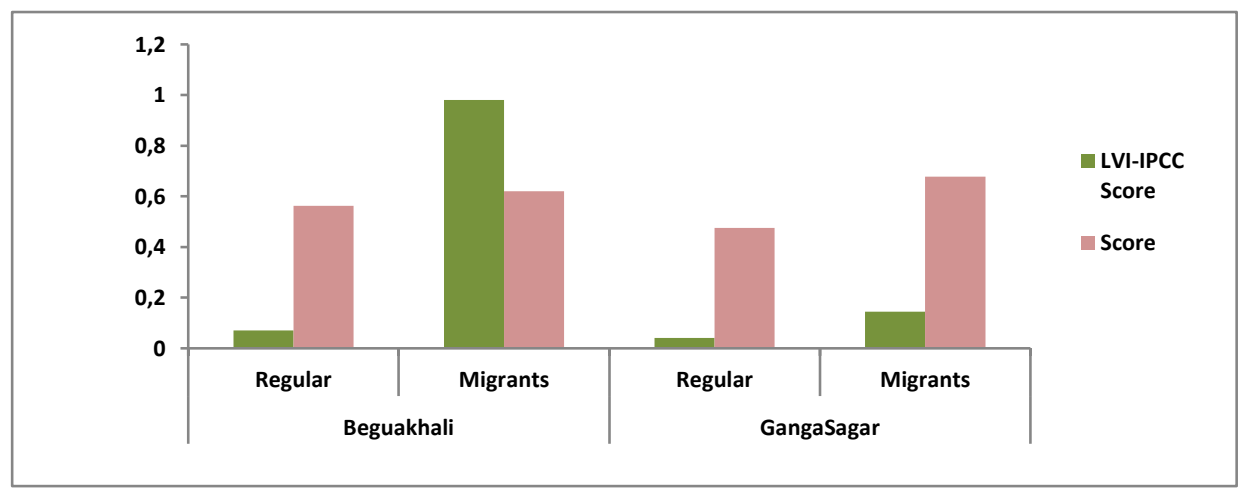

Fig-6: Comparison of LVI \& LVI-IPCC Scores (Source: Computed by author)

This study reveals that a high percentage of households have very low climate resilience with increasing effects of storm surges and embankment breaching. Houses located in marginal areas are damaged every year and people have to live on embankments during the flooding period.

It can be concluded that strengthening of socio-demographic profile and diversification of livelihood options can lead to better adaptation in reducing physical as well as economic vulnerability of the community. Providing trainings of pisciculture, poultry farming, dry fish preparation, artisans and crafts, making small credits and loans easily available can induce self-employment. Quantity and quality development of basic infrastructure \& facilities i;e health care, education, drinking water, transport and communication is utmost required to reduce vulnerability of these migrated people.

As conclusions, people displaced by disruption of physical or social system and degradation of ecosystem services often find them unable to secure a sustainable livelihood in their own habitat. Coastal erosion is causing displacement scenario worldwide and this part of fragile estuaries of river Hugli is no exception. This study analyzed and compared the vulnerability of lives and livelihoods of migrant and regular settlers of Gangasagar gram panchayat of Sagar Island through LVI and LVI-IPCC index scores. People of this constantly shrinking and shrinking landmass of Sundarban delta have been watching their ground slip 
away beneath their feet. The mouzas that experience severe erosion, tidal ingression, embankment breaching, flooding due to the combined effect of sea level rise and complex hydrodynamics scored high vulnerability index values. The climate refugees of these mouzas are more critically vulnerable with their poor socio-demographic profile, livelihood status, poverty, less social security, lower health status and higher exposure to environmental hazards.

The dynamic and complex equation of constantly changing natural system and their functional relationship with society is the key factor for the planning of sustainable management strategies here. Though the dearth of official records of climate related migrations are limiting the efficiency of research at the same time making the rehabilitation policy formation unfeasible. The findings of this study have shown the necessity of vulnerability assessment in a micro scale to identify which sector requires which special management. This is in turn making it valuable for perceiving linkages between climate vulnerability, livelihood, poverty and development for this part of the subsiding delta as well for low lying vulnerable islands worldwide.

\section{REFERENCES}

Abson D J, Dougill A J, Stringer L C, 2012. Using principal component analysis for informationrich socio-ecological vulnerability mapping in Southern Africa. Applied Geography, 35(1-2): 515-524. doi: 10.1016/j.apgeog.2012.08.004.

Cutter S L, Mitchell J T, Scott M S, 2000. Revealing the vulnerability of people and places: a case study of Georgetown county, South Carolina. Annals of the Association of American Geographers, 90(4): 713-737. doi: 10.1111/0004-5608.00219

Census of India, 2011. District Census Handbook South Twenty Four Parganas. West Bengal: Directorate of Census Operations.

Dankelman I, 2010. Climate change, human security and gender. In: Dankelman I (ed). Gender and Climate Change: An Introduction. London: Earthscan.

Ebi K, Kovats R S, Menne B, 2006. An approach for assessing human health vulnerability and public health interventions to adapt to climate change. Environmental Health Perspectives,

Eriksen S H, Kelly P M, 2007. Developing credible vulnerability indicators for climate adaptation policy assessment. Mitigation and Adaptation Strategies for Global Change, 12(4): 495-524. doi: 10.1007/s11027-006-3460-6

FAO, 2007. The state of food and agriculture. In: Food and Agricultural Organization of the United Nations, Rome. Available at http://www.fao.org/docrep/010/a1200e/a1200e00. html. 2017-06-05. 
Sustainability, Agri, Food and Environmental Research, (ISSN: 0719-3726), 9(2), 2021: 216-230 http://dx.doi.org/10.7770/safer-VONO-art2324

Ghosh A, 2012. Living with Changing Climate Impact, Vulnerability and Adaptation Challenges in Indian Sundarbans. New Delhi: Centre for Science and Environment.

Global Sea Level Observing System, 1948-2013. GLOSS data. Available at http://www.glosssealevel.org/data/. 2018-04-15.

Hahn M B, Riederer A M, Foster S O, 2009. The livelihood vulnerability index: a pragmatic approach to assessing risks from climate variability and change-a case studies in Mozambique. Global Environmental Change, 19(1): 74-88. doi: 10.1016/j.gloenvcha.2008.11.002

Hajra R, Ghosh A, Ghosh T, 2017. Comparative assessment of morphological and landuse/landcover change pattern of Sagar, Ghoramara, and Mousani island of Indian Sundarban delta through remote sensing. In:

Hazra S, Ghosh T, DasGupta R et al., 2002. Sea level and associated changes in the Sundarbans. Science and Culture, 68(9-12): 309-321.

Indian Meteorological Department, 1901-2017. Ministry of earth sciences, Government of India. Available at http://www.imd.gov.in/Welcome\%20To\%20IMD/Welcome.php. 2016-05-06.

Inter-governmental Panel on Climate Change (IPCC), 2014. Climate Change 2014: Impacts, Adaptation, and Vulnerability, Contribution of Working Group II to the Fifth Assessment Report of the Intergovernmental Panel on Climate Change.Cambridge, UK: Cambridge University Press.

Mandal S, Choudhury B U, 2015. Estimation and prediction of maximum daily precipitation at Sagar Island using best fit probability models. Theoretical and Applied Climatology,121(1-2): 87-97. doi: 10.1007/s00704-014-1212-1

Mondal I, Bandyopadhyay J, Dhara S, 2017. Detecting shoreline changing trends using principle component analysis in Sagar Island, West Bengal, India. Spatial Information Research,25(1): 67-73. doi: 10.1007/s41324-016-0076-0

Pandey R, Jha S, 2012. Climate vulnerability index-measure of climate change vulnerability to communities: a case of rural lower Himalaya, India. Mitigation and Adaptation Strategies for Global Change, 17(5): 487-506. doi: 10.1007/s11027-011-9338-2

Zhang Yuehong, Wu Shaohong, Dai Erfu et al., 2008. Identification and categorization of climate change risks. Chinese Geographical Science, 18(3): 268-275. doi: $10.1007 / \mathrm{s} 11769-008-0268-1$

Received: $19^{\text {th }}$ September 2020; Accepted: $22^{\text {th }}$ December 2020;

First distribution: 07th January 2021. 